\title{
Methodology of environmental hazards moni- toring in the aspect of air pollutions in sports facilities
}

\author{
Karolina Kuskowska ${ }^{1, *}$ \\ ${ }^{1}$ The Main School of Fire Service, Faculty of Civil Safety Engineering, 52/54 Słowackiego St., \\ 01-629 Warsaw, Poland
}

\begin{abstract}
An overview of the existing literature on the quality of air pollution proves that the majority of research in this field, both in Poland and in the world, concerning particulate matter in atmospheric air, at workstations and less in residential buildings. Due to the above, the methodology in this area is widely available. The problem of particulate matter in sports facilities is decisively different and research conducted in this regards has been so far the subject of only a few publications. Therefore, there are no recommendations about the parameters which should be examined in sports facilities. This is a serious problem because the physical effort increases the frequency and depth of breath, making the PM particles reach more and deeper parts of the human respiratory tracts. Due to the lack of research in this area, this article presents review of methods for monitoring the physicochemical properties of air that are crucial for the health of sports facilities users.
\end{abstract}

\section{Introduction}

Air pollution problem is discussed worldwide by many scientists and institutions for several decades [1-3]. Research in this area mainly focus on the degree of air pollution with suspended particles in various regions of the world; the fractional composition of PM in various areas including a statistical assessment of the mass size distribution [4-7]; chemical composition of aerosol particles with various aerodynamic diameter [5, 7-9]; assessment of the content of PM-bound toxic and carcinogenic compounds [10-12]; the origin of PM in various regions in heating and non-heating seasons; identification of specific or typical sources of various PM fractions [13-15]; particulate matter exposure and health effects to individual PM components [16-18]. There are also research regarding PM concentrations inside different buildings and the indoor and outdoor concentration correlations [19-21]. Based on the available literature search, it can be stated that the sampling sites are constantly repeated and are usually limited to urbanized areas, crossroads, main thoroughfares and industrial areas. However indoor air quality is most often examined in offices, schools including nursery schools, lecture halls and apartments. Due to various parameters affecting the quality of atmospheric air (wind speed, rainfall, surroundings,

\footnotetext{
* Corresponding author: kkuskowska@,sgsp.edu.pl
} 
consistent buildings) and the quality of indoor air (number of air changes, type of ventilation, indoor-outdoor correlation), the methodology for monitoring of air pollutants in atmospheric air is slightly different from the methodology used in measurements of pollution inside of buildings. Nevertheless, both one and the other methodology of measurements of the most important physical and chemical properties of particulate matter which determining the impact on human health are already comprehensively developed.

A brief overview of other objects, which have not been the subject of interest of scientists or institutions dealing with particulate matter research indicates that enclosed sports facilities (gyms, gymnasiums, sports halls) are not recognized in the context of air pollution. Only a few measurements were conducted in these facilities, however they show that the concentrations of particles suspended in the indoor air are higher than concentrations of particles suspended in atmospheric air. [22-26]. Such results may determine a health risk among users of sports facilities because oral breathing usually occurs during intense exercise [26]. Breathing through the mouth causes the omission of the natural respiratory filtration mechanisms in the upper part of the respiratory system. As a result, the amount of particles reaching the deeper parts of the respiratory system is increased. Moreover nasal respiration allows stopping most of the inhaled PM particles with diameters above $2 \mu \mathrm{m}$. The high intensity of breathing while exercising causes not only fine (i.e. less than $2 \mu \mathrm{m}$ in general) but also larger particles to be transferred into the air passages [26-28]. Research into air quality of enclosed sports facilities are also important because in recent years the using of various sports facilities has increased. These facilities, in particular sports halls, are an important part of local public utility buildings performing the functions of communal or urban multifunctional social centres. People spend several hours per day and several times a week in these places. This is also a circumstances for conducting studies in this area.

\section{Methodology}

Taking into account above points determination of the parameters or factors that require monitoring in enclosed sports facilities and the methodology of conducting such monitoring seems to be extremely important. It is necessary to reduce the exposure of users of sports facilities to the adverse effects of indoor air pollution. This paper presents an overview of the methods which should be used in in air pollution's monitoring and is the selection of optimal solutions that, according to the author, should be used in monitoring of the air quality in enclosed sports facilities.

\section{Results and discussion}

According to existing literature data concerning PM, the quality of indoor air is determined by many factors. In the case of sports facilities, due to their purpose, the most important factors are following: thermal and humidity comfort including heat exchange related to physical activity, concentration of carbon dioxide, the ratio of oxygen to carbon dioxide in the air, concentration of various volatile organic compounds (including odours and odorants), microbiological pollution (fungi, viruses, bacteria, mold) and the degree of air pollination [29-30]. The most important in assessing the quality of the indoor air, especially that performed for the purposes of assessing the health exposure among users of sports facilities seems to be the concentration of particles suspended in the air. Two following types of dust can be distinguished in indoor sports facilities [30]:

- $\quad$ settled dust, which can be identified with a coarse PM; it accumulates on various types of surfaces, sports equipment and its presence is generally associated with mechanical 
processes, i.e. running, hitting and bouncing balls, erosion of equipment and building materials,

- suspended dust, which may come mainly or partly from atmospheric air and from internal emission sources.

Research into the concentration of suspended dust results primarily from the need of determination their adverse effect on the human body. This effect depends, inter alia, on particles size therefore PM concentrations should be analysed, according to the following classification [7]:

- inhalation fraction - inhaled particles with an aerodynamic diameter da $\leq 100 \mu \mathrm{m}$ (fine and coarse particles), not penetrating into the alveoli. Particles of this fraction may cause chronic discomfort to the respiratory system and lung diseases,

- tracheal fraction - particles with an aerodynamic diameter da $<30 \mu \mathrm{m}$ which pass through the trachea during breathing. They can contribute to inflammation of the airways, rhinitis, chronic runny nose and even lung cancer,

- respirable fraction - particles with aerodynamic diameter da $<4 \mu \mathrm{m}$ (in the measurement of atmospheric air a diameter of $2.5 \mu \mathrm{m}$ is used), which during breathing can be deposited in the alveoli and dissolved in physiological fluids; worsening asthma symptoms, bronchitis and lung cancer.

The key information in the assessment of health exposure is the dose of contamination, i.e. the mass of substance absorbed into the body within a certain time interval. With regard to particulate matter the dose is absorbed from the air. Due to this the dose is calculated by multiplying the concentration of PM in the air, the absorption coefficient and the residence time in the environment in which the substance is present in the given concentration [29, 31]. The need of the dose calculation determines the choice of the PM concentration measurement method. Results presented in literature show that this method should allow simultaneous measurement of the concentrations of various PM fractions. For example the respirable fraction is the most important in the dose assessment. Moreover the broad spectrum of measured PM fractions also allows for more detailed statistical analyses describing the relationship between various measured quantities or the origin of dust [7, 3233]. The most frequently measured $\mathrm{PM}$ fractions are $\mathrm{PM}_{2.5}, \mathrm{PM}_{10}$, TSP, less frequently $\mathrm{PM}_{1}$ and $\mathrm{PM}_{4}$. The possibilities offered by the measurement of many factions simultaneously are presented, among others, by Widziewicz, Loska and Rogula-Kozłowska. On the basis of the mass size distribution, they created a model thanks to which they examined the size of PM deposition in three regions of respiratory track: head air ways, trachea and bronchiolar, pulmonary alveolar and associated cancer risk [32-33]. In addition to the respirable fraction the concentration of total suspended particles (TSP) is also important in measurements of PM concentrations in sports facilities. Coarse dust settled on the floor, sports equipment surfaces, mattresses, benches etc. may be re-suspended by the movement of exercisers thus affecting the increase in instantaneous concentrations of both the fine and the coarse fraction. Moreover, the accumulation of the fine PM fraction and the formation of large agglomerates is a frequent phenomenon in enclosed sports facilities. The presence of fine particle agglomerates thus causes the increase in the proportion of coarse fraction in total PM concentration. As presented, among others Fromme, Ramos, Bos, PM concentrations of various fractions $\left(\mathrm{PM}_{1}, \mathrm{PM}_{2.5}, \mathrm{PM}_{4}, \mathrm{PM}_{10}, \mathrm{TSP}\right)$ in sports facilities during the day are subjected to large fluctuations associated primarily with the number of people simultaneously performing exercises and the type of discipline practiced (running, football, volleyball, basketball match, gymnastics, wrestling, tennis, etc.) [22-26]. Therefore, measurements in sports facilities should be conducted by the automatic monitors obtaining results in real time, which allow the monitoring of PM concentrations at various times of the measurement, e.g. before training, during training, after leaving the building by the exercisers or depending on the number people training at the same time. The absolute 
standard in measuring of PM concentrations in various places is the gravimetric method based on PM mass deposited on filters within a certain time interval [34-36]. According to standards, this is the reference method [36] but many works proves that it is vulnerable, among others on the influence of dust reactions with air, e.g. desorption or absorption of water vapour, chemical degradation of gaseous pollutants (sulphur oxides $\left(\mathrm{SO}_{2}\right)$, nitrogen oxides $\left(\mathrm{NO}_{\mathrm{x}}\right)$ and volatile organic compounds (VOC)) or the effect of temperature, air humidity on the collected PM and the filter mass itself [37-38]. In addition, the gravimetric method does not provide the ability to track changes in PM concentrations in real time. For these reasons automatic devices that give "on-line" results, allowing measurements with high time resolution are used in the PM concentrations measurements more and more often [39]. Their main disadvantage is that they are not reference devices and should not be equally interpreted as the results of air quality monitoring at Environmental Protection Inspectorate stations. However, many scientists carry out equivalence tests between the non-reference method and the reference method, designating the equivalence factor or correction equation [40-42]. Non-reference devices that could be successfully used in sports facilities after previous equivalence tests carried out in accordance with the methodology specified in the standard [36] or in the EU guide [42] are following: TEOM sampler (Tapered Element Oscillating Microbalance; the measurement method consists in change of frequency of an oscillatory balance) and automatic samplers (DustTrak, Eberline; the measurement method is based on absorption of laser light or beta radiation) [40-41]. Optical meters were used in measurements by, among others Fromme, who studied dust concentration and associated health risk in schools in Munich [8, 43], Ramos, who studied exposure to PM concentrations in fitness centres in Lisbon [25] or Bos and his team who used optical meters for measurements carried out to demonstrate the health effects of training in the urban environment [44]. However, this should be considered that optical meters are sensitive to air humidity and seasonal temperature changes [45-46]. Due to this using of above devices requires parallel measurements of humidity and air temperature. Concomitantly, it will allow to assess thermal and humidity conditions, which also determine the comfort of using sports facilities. Another important factor affecting the concentration of dust in indoor air of sports facilities is their location and surroundings. Until now conducted research proves high concentrations of PM in buildings located in an industrial area, urbanized and/or near street canyon, than in rural areas and significant differences in PM concentrations in the heating and non-heating season [43]. In connection with the above, it is recommended that the monitoring tests should be long-term, covering the cold (heating) and warm (non-heating) season. In order to assess the influence of atmospheric air on indoor air quality, all measurements should be conducted simultaneously indoor and outdoor of the analysed sports facility. The shape, surface and electric charge of dust particles are also important properties of a dust particles occurring inside sports premises. The particles suspended in the indoor air can have very different shapes, e.g. spherical, oval, cubic, cylindrical, elongated, rounded, sharp-edged, etc. [47]. Dust morphology is a parameter determining the dynamics of the spread of the aerosol inside the building and its impact on the human body, but also indicate their origin [48]. For example, all irregular shapes are characteristic for particles formed in the process of coagulation and agglomeration, e.g. particles present in cigarette smoke, generated in mechanical processes, e.g. abrasion of the surface, footwear during exercises, etc. Irregular shapes also have particles which have biological provenance. Liquid aerosol particles are characterized by regular, spherical shapes [47]. According to the existing literature, the most detailed analysis of PM particle morphology is possible by scanning electron microscopes [47]. Electron microscopy is an increasingly common technique that allows for mapping the surface of the tested samples. Currently used high-tech electron microscopes with the function of EDS (Energy Dispersive Spectrometry) allow obtaining 
information on the chemical composition of the observed object, observation of heterogeneity of the tested object invisible when observing other methods, point analysis, linear, surface distribution of elements. This is very useful in the context of assessing the physicochemical properties of particulate matter. Another very important parameter that determines a health risk of exercisers in polluted sports facilities is the chemical composition of particles. The chemical properties of dust affect its volatility, density, reactivity, toxicity. This is decisive importance in the impact of dust pollution on the human body [17]. The most commonly studied PM-bound chemicals affecting health exposure are: polycyclic aromatic hydrocarbons (PAH), which due to proven carcinogenic and mutagenic effects are among the priority substances in the air [49-51] and toxic metals, especially As, $\mathrm{Cd}, \mathrm{Cr}, \mathrm{Hg}, \mathrm{Mn}, \mathrm{Ni}, \mathrm{Pb}$ and $\mathrm{V}$, which according to the WHO classification are on the list of 35 substances particularly dangerous to human health [52]. Therefore, this substance should also be monitored in sports facilities. Also in this area, numerous publications provide methodologies for calculating among others: carcinogenic, mutagenic, toxic, lifetime or daily carcinogenic risk related to inhalation of PM-bound metals and PM-bound PAHs [26, 32-33]. The calculation of these parameters in sports facilities is particularly useful, because in connection with the increased frequency and depth of breath during physical exercise, their values can be many times higher than in other sampling sites (office, school, residential area, etc.). In addition, knowledge of the concentrations of individual PAHs groups allows the calculation of diagnostic ratios which allow to identify the sources of these compounds and possible methods of their elimination or reduction [53]. Monitoring of air quality in sports facilities should also include the analysis of dust precursors, i.e. $\mathrm{SO}_{2}$, $\mathrm{NO}_{\mathrm{x}}$ and VOC. Hourly or daily monitoring of concentrations of these substances will provide information on the processes of chemical changes and reactions occurring in the indoor air, will enable the assessment of potential sources of these compounds and thus sources of PM and most importantly will enable the assessment of PM secondary emission coefficient [54].

\section{Conclusions}

As it was shown above, monitoring of air pollution in enclosed sports facilities, mainly due to the way of breathing of their users connected with physical effort should be carried out systematically. Taking into account the factors and methodology suggested in this paper, will give wide possibilities in identifying of dust sources, assessing of health risk among users of this kind of buildings and take action to reduce PM concentrations. Knowledge of physicochemical properties of PM in enclosed sports facilities, including concentrations of various fractions, i.e. at least $\mathrm{PM}_{1}, \mathrm{PM}_{2.5}, \mathrm{PM}_{4}, \mathrm{PM}_{10}$ and TSP, size mass distribution, chemical composition, especially fine particles, is the basis for determining doses PM absorbed by athletes, both during training, in a longer time (several years) and lifetime and for the assessment of carcinogenic risk associated with exposure to PM-bound toxic components $[32-33,55]$. The review conducted in this paper also proves that the analysis of the health risk associated with PM deposition in respiratory tract of exercisers should always include at least two-time increase in lung minute ventilation during exercise [5657]. This means that comparing only the results of PM concentrations between sports facilities and other buildings, without calculating the doses may lead to poor interpretation of the air quality status. Limiting measurements only to PM concentrations will not show the level of exposure of exercisers to the conditions prevailing in the given sports facility.

The authors would like to acknowledge the Ministry of Higher Education for their financial support as part of statutory work under the number $\mathrm{S} / \mathrm{E} / 422 / 8 / 16 / 17$. This article is the main aspects of the methodology used by the author in the prepared $\mathrm{PhD}$ dissertation "Analysis of hazards related to 
physicochemical properties of dust in the air of selected sports facilities" under supervision of Prof Wioletta Rogula-Kozłowska at The Main School of Fire Service, Faculty of Fire Safety Engineering (Warsaw). I would like to thank to my supervisor for her constant support and constructive suggestions, which were determinant for the accomplishment of the work.

\section{References}

1. J. Juda, Pomiary zapylenia $i$ technika odpylania (Wydawnictwo NaukowoTechniczne, Warszawa, 1968)

2. J. Schwartz, Health effects of air pollution from traffic: ozone and particulate matter, Health at the Crossroads. Transport Policy and Urban Health, W.T. Fletcher, A. McMichael (ed.) (Chichester, John Wiley \& Sons, 61-82, 1997)

3. W.C. Hinds, Aerosol Technology: Properties, Behavior and Measurement of Airborne Particles (John Wiley \& Sons, Inc. New York, 1998)

4. P. DeCarlo, J. Slowik, D. Worsnop, P. Davidovits, J. Jimenez, Aerosol Sci. Tech. 38, 1185-1205 (2004)

5. K. Klejnowski, J. Pastuszka, W. Rogula-Kozłowska, E. Talik, A. Krasa, Bull. Environ. Contam. Toxicol. 88, 255-259 (2012)

6. L. Morawska, S. Thomas, M. Jamriska, G. Johnson, Atmos. Environ. 33, 4401-4411 (1999)

7. W. Rogula-Kozłowska, Air Qual. Atmo. Health 9, 533-550 (2016)

8. H. Fromme, J. Diemer, S. Dietrich, J. Cyrys, J. Heinrich, W. Lang, D. Twardella, Atmos. Environ. 42, 6597-6605 (2008)

9. F. J. Kelly, J.C. Fussell, Atmos. Environ. 60, 504-526 (2012)

10. M. Bełdowska, D. Saniewska, L. Falkowska, A. Lewandowska, Atmos. Environ. 46, 397-404 (2012)

11. A. Mainka, E. Zajusz-Zubek, K. Kaczmarek, Int. J. Environ. Res. Public Health 12, 7990-8008 (2015)

12. International Agency for Research on Cancer, A review of Human Carcinogens: Arsenic. Metals. Fibres. and Dusts, IARC Monographs on the Evaluation of Carcinogenic Risks to Humans (IARC, 2012)

13. B. Bessagnet, A. Hodzic, O. Blanchard, M. Lattuati, O. Le Bihan, H. Marfaing, L. Roull, Atmos. Environ. 39, 6159-6174 (2005)

14. W. Rogula-Kozłowska, G. Majewski, B. Błaszczak, K. Klejnowski, P. Rogula-Kopiec, Int. J. Environ. Res. Public Health 13, 715 (2016)

15. J.S. Pastuszka, W. Rogula-Kozłowska, E. Zajusz-Zubek, Environ. Monit. Assess. 168, $613(2010)$

16. A. Abelsohn, D.M. Stieb, Can. Fam. Physician, 57,8, 881-887 (2011)

17. T. de Kok, H. Driece, J. Hogervorst, J. Briedé, Mutat. Res. 613, 103-122 (2006)

18. I. Sówka, Ł. Pachurka, M. Przepiórka, W. Rogula-Kozłowska, A. Zwoździak, Rocz. Ochr. Śr., 18, 610-622 (2016)

19. D. Dockery, J. Spengler, Atmos. Environ. 15, 335-343 (1981)

20. N. Jones, C. Thornton, D. Mark, R. Harrison, Atmos. Environ. 34, 2603-2612 (2000)

21. P. Rogula-Kopiec, J. Pastuszka. W. Rogula Kozłowska. G. Majewski, Annals of Warsaw University of Life Sciences - SGGW 47, 1 (2015) 
22. C. Alves, A. Calvo, A. Castro, R. Fraile, M. Evtyugina, E. Bate-Epey, Int. J. Environ. Chem. Ecol. Geo. Geophysic. Eng., 7, 6 (2013)

23. M. Branis, J. Safranek, Environ. Res. 111, 4 (2011)

24. M. Hajian, S. Mohaghegh, Int. J. Medical Toxicology and Forensic Medicine 5, 22-31 (2015)

25. C. Ramos, H. Wolterbeek, S. Almeida, Build. Environ. 82, 349-360 (2014)

26. K. Kuskowska, W. Rogula-Kozłowska, P. Rogula-Kopiec, E3S Web of Conferences 28, 01020 (2018)

27. C. Daigle, D. Chalupa, F. Gibb, P. Morrow, G. Oberdörster, M. Utell, M. Frampton, Inhal. Toxicol. 15, 539-552 (2003)

28. V. Niinimaa, P. Cole, S. Mintz, Respir Physiol, 42, 61-71 (1980)

29. J.S. Pastuszka, Higiena pracy w pomieszczeniach nieprzemysłowych, Higiena Pracy, J.A. Indulski (ed.) (Łódź, 1999)

30. L. Morawska, T. Salthammer, Indoor environment: airborne particles and settled dust (John Wiley \& Sons, 2006)

31. W.R. Ott, Journal Air Waste Manage. Assoc. 40, 966-975 (1990)

32. K. Widziewicz, W. Rogula-Kozłowska, Atmos. Pollut. Res. 9, 399-410 (2018).

33. K. Widziewicz, W. Rogula-Kozłowska, K. Loska, Atmos. Pollut. Res. 7, 5 (2016)

34. Federal Register, Revised requirements for designation of reference and equivalent methods for PM2.5 and ambient air quality surveillance for particulate matter, Final Rule: 40 CFR Parts 53 and 58 (Federal Register 62, 38764, 1997)

35. EC, Council directive 1999/30/EC relating to limit values for sulphur dioxide, nitrogen oxide and oxides of nitrogen, particulate matter and lead in ambient air (Official Journal of the European Communities, L163, 41-60, 1999)

36. CEN, Air Quality-Determination of the PM10 fraction of suspended particulate matter-Reference method and field test procedure to demonstrate reference equivalence of measurement methods (EN 12341, 1998)

37. A.D. Eisner, R.W. Wiener, Aerosol Sci. Technol. 36, 433-440 (2002)

38. Y. Pang, N.L. Eatough, D.J. Eatough, Aerosol Sci. Technol. 36, 277-288 (2002)

39. M. Bogacki, R. Oleniacz, M. Mazur, S. Kamiński, Environ. Prot. Eng. 32, 69-74 (2006)

40. J. Gębicki, K. Szymańska, Pol. J. Environ. Stud. 20, 1465-1472 (2011)

41. J. Gębicki, K. Szymańska, Atmos. Environ. 54, 18-24 (2012)

42. EC, Demonstration of Equivalence of Ambient Air Monitoring Methods (EC Working Group on Guidance for the Demonstration of Equivalence, 2005)

43. H. Fromme, D. Twardella, S. Dietrich, D. Heitmann, R. Schierl, B. Liebl, H. Ruden, Atmos. Environ. 41, 854-866 (2007)

44. I. Bos, P. De Boever, J. Vanparijs, N. Pattyn, L.I Panis, R. Meeusen, Med. Sci. Sports Exerc. 45, 439-47 (2013)

45. L. Fang, G. Clausen, P.O. Fanger, Int. J. Indoor Environ. Health 8, 80-90 (1998)

46. I. Rivas, M. Mazaheri, M. Viana, T. Moreno, S. Clifford, C. He, O.F. Bischof, V. Martins, C. Reche, A. Alastuey, M. Alvarez-Pedrerol, J. Sunyer, L. Morawska, X. Querol, Sci Total Environ. 584, 849-855 (2017) 
47. M. Jabłońska, Skład fazowy pyłów atmosferycznych $w$ wybranych miejscowościach Górnośląskiego Okręgu Przemystowego (Wydawnictwo Uniwersytetu Śląskiego, Katowice, 2003)

48. P.A. Baron, K. Willeke, Aerosol measurement: principle,. technique and applications (2nd ed, 2001)

49. J. Durant, W.J. Busby, A. Lafleur, B. Penman, C. Crespi, Mutat Res. 371, 123-157 (1996)

50. K.H. Kim, S.A. Jahan, E. Kabir, R.J.C. Brown, Environ. Int., 60, 71-80 (2013)

51. D.S. Jyethi, P.S. Khillare,S. Sarkar, Environ. Sci. Pollut. Res., 21, 366-378 (2014)

52. M. Reizer, Co to jest pyt zawieszony?, Pyły drobne w atmosferze, K. Juda-Rezler, B. Toczko (ed.) (Biblioteka Monitoringu Środowiska, Warszawa, 11-21, 2016)

53. W. Rogula-Kozłowska, PAH and Heavy Metals in Ambient Particulate Matter: A Review of Up-to-Date Worldwide Data, Synergic Influence of Gaseous, Particulate, and Biological Pollutants on Human Health,J.S. Pastuszka (ed.), CRC Press, 68-108 (2015)

54. A. Degórska, Źródła emisji pyłu pierwotnego. Pyły drobne w atmosferze, K. JudaRezler, B. Toczko (ed.) (Biblioteka Monitoringu Środowiska, Warszawa, 22-26, 2016)

55. A. Zwoździak, M. Gini, L. Samek, W. Rogula-Kozlowska, I. Sówka, J. Aerosol Sci. 103 (2016)

56. M. Sracic, J. Aerosol Sci. 99, 54-63 (2016).

57. J.C. Naranjo, J. Sports Med, 39, 80-83 (2005) 